\title{
ANALISIS AKUNTANSI DANA INVESTASI ASURANSI UMUM SYARIAH DAN KONVENSIONAL SERTA PERLAKUAN TERHADAP HASIL INVESTASI (Studi Kasus Pada PT. Asuransi Asei Indonesia)
}

\author{
Reynaldi Muhammad ${ }^{1}$, Jantje J. Tinangon ${ }^{2}$, Treesje Runtu ${ }^{3}$ \\ ${ }^{123}$ Fakultas Ekonomi dan Bisnis, Jurusan Akuntansi, Universitas Sam Ratulangi, Jl.Kampus Bahu, Manado \\ 95115, Indonesia \\ E-mail: reynaldi_muhammad@ hotmail.com
}

\begin{abstract}
This case study discusses the accounting treatment of investment funds from sharia and conventional insurance products at PT Asuransi Asei Indonesia. Thats matter supported by the differences in principles and standards governing the shariah and conventional insurance business. The purpose of this research is to know the activity of investment fund management conducted by PT. Asuransi Asei Indonesia on sharia and conventional insurance products. Data analysis method used in this research is descriptive, with qualitative approach. The results of the study reveal the application of accounting and revenue sharing of investment funds, in accordance with generally accepted accounting principles and standards, namely PSAK 108 for sharia insurance and PSAK 28 for conventional insurance. from the results of the research can be concluded that the placement of investment instruments by the company by following the PMK No.11/PMK.010/2011 and PMK No.53/PMK.010/2012 are in accordance with the principles and standards of sharia and conventional insurance. It is expected that the company remains obedient to regulated investment limits. And it is better to open a sharia link unit to really separate the shariabased and conventional-based insurance business.
\end{abstract}

Keywords: General Insurance, profit sharing, investment funds, PSAK 108

\section{PENDAHULUAN}

1.1 Latar Belakang

Dalam perusahaan asuransi yang berbasis konvensional maupun syariah terdapat dua macam dasar usaha asuransi yang kita ketahui yaitu usaha asuransi umum (kerugian) dan usaha asuransi jiwa. Usaha Asuransi Umum atau juga disebut Asuransi Kerugian merupakan perjanjian asuransi yang memberikan jasa dalam penanggulangan risiko atas kerugian, kehilangan manfaat, dan tanggung jawab hukum kepada pihak ketiga yang timbul dari peristiwa yang tidak pasti (Ichsan: 2016).

Seiring dengan perkembangannya saat ini hampir semua perusahaan asuransi membentuk unit syariah. Bahkan asuransi asing juga ikut membuka unit syariah. Namun masyarakat masih minim dengan pengetahuan asuransi. Apalagi ketika telah disandingkan dengan nama syariah, tentu lebih banyak istilah yang perlu diketahui. Menurut Fatwa Dewan Syariah Nasional No. 21/DSN-MUI/X/2001, asuransi syariah (Ta'min, Tafakul, atau Tadhaman) adalah usaha saling melindungi dan tolong menolong diantara sejumlah orang atau pihak melalui investasi dalam bentuk aset dan/atau Tabarru' yang memberikan pola pengembalian untuk menghadapi risiko tertentu melalui akad (perikatan) yang sesuai dengan syariah. (Muljono, 2015:452)

Menurut para ahli asuransi syariah, dalam mekanisme asuransi konvensional, paling tidak ada tiga hal yang masih diharamkan oleh para ulama, yaitu adanya unsur Gharar (ketidakjelasan dana), unsur Masyir (judi/gambling), dan Riba (bunga). Hal itu disebabkan oleh adanya beberapa perbedaan prinsip-prinsip yang berlaku antara asuransi yang bersifat 
syariah dan asuransi secara konvensional. Selain perbedaan prinsip terdapat juga perbedaan standar pencatatan yang berlaku umum antara akuntansi asuransi syariah yang berdasarkan PSAK 108 "Transaksi akuntansi asuransi syariah", sedangkan asuransi konvensional yang berdasarkan PSAK 28 "Akuntansi asuransi kerugian". Salah atu perbedaan diantara PSAK 28 dan PSAK 108 adalah pada pengakuan pendapatan premi. Apabila merujuk pada PSAK 28, premi tersebut masuk dalam pendapatan perusahaan. Sedangkan PSAK 108 menggunakan istilah kontribusi yang diakui sebagai bagian dari dana Tabarru' dalam dana peserta. Kontribusi (premi) dipisahkan menjadi Ujrah dan Tabarru', dimana kumpulan dana Tabarru' sepenuhnya milik peserta asuransi yang dikelola dan diinvestasikan sesuai syariah. sedangkan Ujrah merupakan zakat atau fee untuk perusahaan dan digunakan untuk pengelolaan perusahaan. Studi kasus ini dilakukan pada PT. Asuransi Asei Indonesia karena merupakan perusahaan yang memberikan jasa asuransi umum/kerugian berbasis konvensional dan syariah kepada masyarakat.

Dari latar belakang masalah yang telah diuraikan, maka penulis merumuskan masalah yang akan dibahas yaitu apakah penerapan akuntansi dan perlakuan terhadap hasil investasi serta pembagian hasil investasi, dari produk asuransi berbasis syariah dan konvensional pada PT. Asuransi Asei Indonesia sudah sesuai dengan standar yang berlaku umum ?

Tujuan penelitian untuk mengetahui implementasi akuntansi dana investasi dan perbedaan pengelolaan dana investasi dari produk asuransi syariah dan konvensional pada PT. Asuransi Asei Indonesia.

\section{TINJAUAN PUSTAKA}

\subsection{Pengertian Akuntansi}

"Accounting was defined as the art of recording, classifying and summarizing in a meaningful way and in monetary value, the actions that are least of a financial nature and the interpretation of these results" (Zybery and Rova, 2014). Akuntansi merupakan seni pencatatan, pengklasifikasian dan pengikhtisaran dalam cara yang signifikan dan dalam satuan mata uang, transaksi-transaksi dan kejadian-kejadian yang paling tidak sebagian diantaranya, memiliki sifat keuangan dan selanjutnya menginterpretasikan hasilnya.

Akuntansi Keuangan (financial Accounting) merupakan proses yang berpuncak pada penyiapan laporan keuangan perusahaan secara menyeluruh untuk digunakan oleh pihak internal dan eksternal perusahaan dalam rangka pengambilan keputusan (Horman, 2016).

\subsection{Konsep Ekonomi Islam}

Menurut Husin (2016:119) Sebagai pedoman hidup (minhajul hayah) islam memiliki konsepsi lengkap (syamil) dan sempurna (kamil) atas seluruh aspek kehidupan dan kesemuanya terintegrasi. Islam mengakui atau menyadari bahwa kepemilikan manusia atas benda-benda ekonomi bersifat amanah dari pemilik asal (Allah SWT). Oleh karena itu, setiap kegiatan ekonomi tidak dibenarkan bertentangan dengan kehendak Allah, dan hak-hak-Nya atas harta setiap individu (hak sosial) wajib dikeluarkan. Dalam (Al-Quran Surat Yunus ayat 55) disebutkan bahwa "ingatlah, sesungguhnya kepunyaan Allah apa yang ada di langit dan di bumi. Ingatlah, bahwa janji Allah itu benar, tetapi kebanyakan mereka tidak mengetahui(Nya)". Islam dan ekonomi memiliki hubungan yang berkelindan (erat,menjadi satu), saling terkait dan sulit dipisahkan. Setiap perolehan ekonomi harus dipastikan kehalalannya baik dari segi sumber cara memperolehnya maupun penggunaannya.

\subsection{Pengertian dan Prinsip Asuransi Syariah}

Berdasarkan definisi dalam PSAK 108 Asuransi Syariah adalah sistem menyeluruh yang pesertanya mendonasikan (menTabarru'kan) sebagian atau seluruh kontribusinya yang digunakan untuk membayar klaim atas risiko tertentu akibat musibah pada jiwa, badan, atau benda yang dialami oleh peserta yang berhak. Donasi tersebut merupakan milik peserta secara kolektif, bukan merupakan pendapatan entitas pengelola. Menurut Abrori (2013) 
Asuransi syariah adalah sebuah sistem dimana para peserta asuransi mendonasikan/menghibahkan sebagian atau seluruh kontribusi yang digunakan untuk membayar klaim, jika terjadi musibah yang dialami oleh sebagian lainnya. Peranan perusahaan disini hanya sebagai pengelola dana operasional perusahaan asuransi serta investasi dari premi yang diterima. Dalam PSAK 108 menyebutkan prinsip dasar dalam asuransi syariah adalah saling tolong menolong (Ta'awuni) dan saling menanggung (Tafakuli) antara sesama peserta. Dalam hukum Islam yang mendasari prinsip asuransi syariah Sebagaimana firman Allah SWT. Dalam (Al-Quran surat Al-Maidah ayat 2) yang artinya: "dan tolong menolonglah kamu dalam mengerjakan kebajikan dan takwa, dan jangan tolong menolong dalam berbuat dosa dan pelanggaran Dan bertakwalah kamu kepada Allah, sesungguhnya Allah amat berat siksa-Nya”.

\subsection{PSAK 108 (Revisi 2015) Akuntansi Transaksi Asuransi Syariah}

Pernyataan Standar Akuntansi Keuangan 108: Akuntansi Transaksi Asuransi Syariah terdiri dari paragaf 1-43 seluruh paragraf dalam pernyataan ini memiliki kekuatan mengatur yang sama. Paragraf ini mengatur prinsip-prinsip utama. Pernyataan ini harus dibaca dalam konteks kerangka dasar penyusunan laporan keuangan syariah.

1) Tujuan pernyataan ini untuk mengatur pengakuan, pengukuran, penyajian, dan pengungkapan transaksi asuransi syariah.

2) Transaksi Asuransi Syariah yang dimaksud adalah transaksi yang terkait dengan kontribusi peserta, surplus, dan deficit underwriting, penyishan teknis dan saldo dana Tabarru'.

3) Akad yang digunakan dalam asuransi syariah adalah akad Tabarru' dan akad Tijarah. Akad Tabarru' digunakan diantara para peserta, sedangkan akad Tijarah digunakan antara peserta dengan entitas pengelola.

4) Pembayaran manfaat atau klaim asuransi berasal dari dana peserta secara kolektif (Dana Tabarru').

5) Kontribusi peserta diakui sebagai pendapatan dana Tabarru'. Kontribusi peserta bukan merupakan pendapatan entitas pengelola karena entitas pengelola merupakan wakil para peserta untuk mengelola dana Tabarru'. Dana tersebut milik peserta secara kolektif.

6) Selain dari kontribusi peserta, perubahan saldo dana Tabarru' juga berasal dari hasil investasi dana Tabarru' dan surplus atau defisit underwriting dana Tabarru'. Entitas pengelola melakukan investasi dari dana Tabarru' dalam kedudukannya sebagai wakil para peserta (jika menggunakan akad wakalah) atau pengelola dana (jika menggunakan akad mudharabah musytarakah).

7) Perlakuan untuk hasil investasi dengan akad mudharabah musytarakah, dan Wakalah bil Ujrah mengacu pada PSAK yang relevan.

8) Bagian kontribusi untuk Ujrah diakui sebagai pendapatan entitas pengelola secara garis lurus selama masa akad dan menjadi beban dana Tabarru'. Biaya akuisisi diakui entitas sebagai beban entitas pengelola selaras dengan pengakuan pendapatan Ujrah tersebut.

\subsection{Pengertian dan Prinsip Asuransi Konvensional}

Tahira \& Arshad (2014) Insurance provides the means for people to transfer the

burden of uncertainty to the insurer, for an agreed financial consideration called the premium. In exchange, the insurer promise to provide financial compensation to the insured should a specified loss occur. It is also called risk transfer mechanism in which one can exchange his uncertainty of financial loss for the certainty of the premium. Asuransi menyediakan sarana bagi orang untuk mengalihkan beban ketidakpastian kepada perusahaan asuransi, untuk pertimbangan keuangan yang disebut premi. Sebagai gantinya, perusahaan berjanji untuk memberikan kompensasi financial kepada tertanggung jika terjadi kerugian tertentu. Hal ini juga di sebut mekanisme transfer risiko dimana seseorang dapat menukarkan ketidakpastiannya akan kerugian financial untuk kepastian premi. 
The basic idea of insuransce agreement is that it is a mutual cooperation between two parties to protect one of them from unexpected future financial loss. Ide dasar dari perjanjian asuransi adalah kerjasama saling menguntungkan antara dua pihak untuk melindungi salah satu, dari kerugian financial tak terduga di masa depan (Pasha, 2011). Sumber asuransi konvensional berlandaskan pada Undang-Undang yang menjadi regulator asuransi konvensional di Indonesia, tercantum dalam Undang-Undang Republik Indonesia No.40 Tahun 2014 tentang Perasuransian. Yang menggantikan Undang-Undang No.2 Tahun 1992 Usaha perasuransian. sebagai berikut: "Asuransi Adalah Perjanjian Antara dua pihak, yaitu perusahaan asuransi dan pemegang polis, yang menjadi dasar bagi penerimaan premi oleh perusahaan asuransi sebagai imbalan untuk memberikan pergantian kepada tertanggung atau pemegang polis karena kerugian, kerusakan, biaya yang timbul, kehilangan keuntungan atau tanggung jawab hukum kepada pihak ketiga yang mungkin diderita tertanggung atau pemegang polis karena terjadinya suatu peristiwa yang tidak pasti”.

\subsection{PSAK 28 Revisi 2012}

Pernyataan standar akuntansi keuangan 28 ini merupakan standar yang mengatur tentang Akuntansi asuransi kerugian. beberapa bunyi pernyataan standar yang terdapat dalam PSAK 28

1) Premi bruto adalah premi yang diperoleh dari tertanggung, agen, broker, maupun dari perusahaan asuransi lain dan perusahaan reasuransi. Premi bruto yang berasal pertanggungan langsung dinamakan premi langsung, sedangkan premi yang diterima dari perusahaan asuransi lain atau perusahaan reasuransi dinamakan premi tidak langsung. Premi yang diperoleh diakui sebagai pendapatan berdasarkaan accrual basis yang dialokasikan secara merata selama masa pertanggungan.

2) Klaim adalah ganti rugi yang dibayarkan atau yang menjadi kewajiban kepada tertanggung atau perusahaan asuransi (ceding company) sehubungan dengan telah terjadinya kerugian. Beban klaim diakui dan dicatat bersamaan dengan timbulnya kewajiban kepada tertanggung yaitu pada periode tercapainya persetujuan ganti rugi kepada tertanggung.

3) Pendapatan underwriting adalah pendapatan yang diperoleh dari aktivitas pokok perusahaan asuransi. Komponen-komponen pendapatan underwriting (premi tanggungan sendiri) terdiri dari: premi bruto, dikurangi: premi reasuransi dan dikurang/ditambah: kenaikan/penurunan premi yang belum merupakan pendapatan.

4) Lazimnya dalam bidang usaha asuransi kerugian, investasi (penyertaan) merupakan salah satu kegiatan pengelolaan dana yang utama diluar usaha asuransi. Dengan demikian akun ini disajikan pada urutan utama pada aktiva. Investasi ditujukan antara lain untuk: memperoleh keuntungan, menjamin solvabilitas perusahaan, menunjang kegiatan operasional asuransi (pembayaran klaim).

\subsection{Investasi}

dalam Sawitri (2012) Investasi merupakan penanaman dana dalam jumlah tertentu pada saat ini untuk mendapatkan hasil yang lebih besar dimasa yang akan datang. Investasi bisa juga dikatakan proses menabung yang berorientasi pada tujuan tertentu dan bagaimana mencapai tujuan tersebut. Jadi investasi memiliki perbedaan dengan tabungan yang kurang memiliki tujuan secara spesifik dan kejelasan metode atau strategi dalam mencapai tujuan.

Instrumen Investasi merupakan sarana-sarana atau wadah yang telah ada dan dipilih perusahaan/orang per seorangan untuk menyalurkan dana atau barang untuk di investasikan guna mendapatkan keuntungan (return) yang ingin dicapai. Instrumen investasi syariah di Indonesia saat ini sedang tumbuh dan berkembang, adapun beberapa kekayaan yang diperkenankan dalam bentuk investasi syariah telah diatur oleh peraturan menteri keuangan dalam PMK No. 11/PMK.010/2011. sedangkan Instrumen investasi konvensional juga telah diatur oleh peraturan menteri keuangan dalam PMK No.53/PMK.010/2012. 


\section{METODE PENELITIAN}

\subsection{Jenis \& Sumber Data}

Jenis data yang digunakan kualitatif dan kuantitatif, yaitu :

1) Data kualitatif karena menggambarkan tentang kondisi pengelolaan dana premi yang di investasikan, serta perlakuan atas hasil investasi tersebut berdasarkan prinsip akuntansi syariah dan konvensional di PT.Asuransi Asei Indonesia

2) Data kuantitatif karena menggambarkan tentang perlakuan, pengakuan dan pencatatan dari dana investasi tersebut. Dimana data kuantitatif disini berupa bagian dari laporan keuangan yang akan digambarkan dan dijelaskan.

Surwajeni (2014:73) menyatakan sumber data adalah subjek dari mana asal data penelitian yang diperoleh. Data yang digunakan adalah:

1) Indrianto dan Supomo (2014:145) data primer merupakan sumber data penelitian yang diperoleh secara langsung dari sumber asli (tidak melalui media perantara). Sumber data primer dalam penelitian ini yaitu melakukan penelitian langsung ke PT. Asuransi Asei Indonesia kantor cabang Manado untuk mendapatkan data berupa mekanisme pengelolaan dana investasi dan perlakuan hasil investasi tersebut dalam laporan keuangan selama beberapa tahun terakhir.

2) Indrianto dan Supomo (2014:147) menyatakan data sekunder merupakan sumber data penelitian yang diperoleh peneliti secara tidak langsung melalui media perantara (diperoleh dan dicatat oleh pihak lain). Sumber data sekunder dalam penelitian ini yaitu diperoleh dari buku-buku, pencarian informasi internet dan PSAK yang berlaku umum.

\subsection{Metode Analisis Data}

Metode analisis yang digunakan dalam penelitian ini bersifat deskriptif kualitatif dengan tujuan untuk memberikan gambaran yang mendetail tentang objek yang diteliti dan mengetahui tentang mekanisme pengelolaan dana investasi dari produk asuransi syariah dan konvensional serta menguraikan data-data yang diperoleh dari PT.Asuransi Asei Indonesia kantor cabang Manado. Data-data tersebut kemudian dibandingkan dengan PSAK 28 dan PSAK 108. sehingga bisa ditarik kesimpulan mengenai pengelolaan dana investasi pada produk asuransi syariah dan konvensional di PT. Asuransi Asei Indonesia.

\section{HASIL ANALISIS DAN PEMBAHASAN \\ 4.1 Hasil Analisis}

\section{1) Pengelolaan, Pencatatan, Pembagian Hasil Dana Investasi Asuransi Syariah}

Asuransi Umum Syariah yang di tawarkan oleh PT Asuransi Asei Indonesia terbagi beberapa produk yaitu Asuransi Harta Benda Syariah, Asuransi Rekayasa Syariah, Asuransi Pengangkutan Barang Syariah, Asuransi rangka Kapal Syariah, Asuransi Uang Syariah, dan Asuransi Aneka Syariah. Semua produk asuransi tersebut menggunakan akad Tabarru' antara para peserta asuransi, dan Wakalah bil ujrah antara peserta dan perusahaan. maka perusahaan sebagai pihak yang diberi kuasa berhak mengelola dana dan mendapatkan Ujrah (Fee) dari hasil investasi tersebut.

Pencatatan Akuntansi yang dilakukan oleh Divisi Keuangan\&Investasi perusahaan dalam kegiatan usaha berbasis Syariah dan Konvensional dilakukan terpisah dan kemudian akan dikonsolidasikan menjadi satu kesatuan laporan keuangan. Sesuai dengan akad Tabarru' yang disepakati antara peserta dan perusahaan, pada setiap produk Asuransi Syariah. Perusahaan mengakui Iuran kontribusi (premi) yang dibayarkan peserta, sebagian diakui sebagai pendapatan Dana Tabarru' dan sebagian sebagai Ujrah (fee) untuk perusahaan. Selaras dengan itu perusahaan mencatat Iuran Ujrah/fee dicatat sebagai pendapatan (Ujrah,) serta Iuran Tabarru' dicatat sebagai Dana Tabarru'. selanjutnya dalam kegiatan investasi, hasil investasi di catat sebagai pendapatan investasi, yang di alokasikan ke Pendapatan Perusahaan dan Dana Tabarru'. Hal ini yang telah sesuai dengan PSAK 108, 
dimana hasil dari kegiatan investasi atas dana Tabarru' dilakukan pembagian hasil sesuai dengan akad wakalah bil ujrah yang digunakan antara perusahaan dan peserta asuransi.

\begin{tabular}{cccc}
\hline Kontribusi & Klaim & Investasi & Hasil Investasi \\
\hline Dana Tabarru' & Beban klaim & Depsito Syariah & Kas \\
Pendapatan Tabarru' & Dana Tabarru' & Dana Tabarru' & Pendapatan \\
Kas & & Sukuk & investasi \\
Pendapatan ujrah & & Dana Tabarru' & \\
& & Deposito/Sukuk & Dana Tabarru' \\
& & Dana Tabarru' & Pendapatan investasi
\end{tabular}

Dalam PT Asuransi Asei Indonesia, pembagian hasil dana investasi pada produk asuransi syariah dilakukan seperti yang tercantum pada Akad/Polis. Dimana dana kontribusi yang disetorkan peserta asuransi akan dialokasikan dan dipisah menjadi dua unsur yaitu:

1) Wakalah Fee (Ujrah) sebesar : $40 \%$ dari kontribusi,

2) Iuran Tabarru' sebesar $\quad: 60 \%$ dari dana Kontribusi.

Selanjutnya dana Tabarru' dikelola perusahaan dengan diinvestasikan untuk mendapatkan keuntungan (return), kemudian hasil investasi dari dana Tabarru' akan dialokasikan sesuai nisbah bagi hasil antara peserta dan perusahaan yakni:

1) sebagai ujrah (komisi) perusahaan mendapatkan : $50 \%$

2) sisanya dimasukan sebagai cadangan Tabarru' :50\%.

2) Pengelolaan, Pencatatan, Pembagian Hasil Dana Investasi Asuransi Syariah

mekanisme pengelolaan dana pada produk asuransi umum konvensional di PT Asuransi Asei Indonesia tidak ada pemisahan antara dana wakalah dan dana Tabarru', semua dana premi yang di setorkan peserta asuransi kepada perusahaan bercampur menjadi satu. karena akad yang digunakan perusahaan dalam produk asuransi umum konvensional adalah murni akad jual-beli, perusahaan menjual jasa pertanggungan yang bersedia menanggung segala risiko peserta asuransi (tertanggung) dengan konsekuensi peserta asuransi (tertanggung) membayar premi, sesuai dengan yang tertera dalam kontrak polis asuransi. Perusahaan mengakui premi yang di peroleh perusahaan atas perjanjian polis sudah menjadi pendapatan dan hak seutuhnya bagi perusahaan, kewajiban perusahaan hanya pada saat membayar klaim peserta. Maka dari itu perusahaan memiliki kebebasan dalam mengelola dan menginvestasikan dana ke mana saja tanpa ada pembatasan halal ataupun haram.

Pencatatan Akuntansi yang dilakukan oleh Divisi Keuangan\&Investasi Perusahaan, atas kegiatan usaha berbasis Syariah dan Konvensional dilakukan terpisah dan kemudian akan dikonsolidasikan menjadi satu kesatuan laporan keuagan. Pada setiap produk Asuransi Umum Konvensional, perusahaan mengakui setoran uang dari peserta atau disebut juga dengan premi diakui sebagai pendapatan langsung perusahaan dan dicatat sebagai pendapatan premi. Kemudian hasil dari investasi atas dana premi tersebut juga di akui sepenuhnya sebagai pendapatan perusahaan dan dicatat sebagai pendapatan investasi. Pencatatan atas dana investasi sudah dilakukan sesuai PSAK yang relevan. dan tidak ada kewajiban bagi perusahaan untuk melaporkan kinerja dan hasil investasi kepada peserta.

\begin{tabular}{cccc}
\hline \multicolumn{1}{c}{ Penerimaan Premi } & Klaim & Investasi & Hasil Investasi \\
\hline Kas & Beban klaim & Efek & Kas \\
Pendapatan premi & Kas & Kas & Pendapatan investasi \\
& & Obligasi & \\
& & Kas \\
& Reksadana \\
& & Kas &
\end{tabular}

Dalam produk asuransi umum konvensional yang ditawarkan PT Asuransi Asei Indonesia, pembagian hasil atas dana investasi. Sesuai kontrak dalam polis yang murni menggunakan akad jual beli atas jasa pertanggungan, tidak ada pembagian hasil antara perusahaan dengan peserta asuransi, tetapi pembagian hasil investasi hanya dilakukan antara perusahaan dengan pemegang saham, selaku pemilik modal perusahaan. 


\subsection{Pembahasan}

\section{1) Penerapan Akuntansi Dana Investasi a. Produk Asuransi Konvensional}

\begin{tabular}{|c|c|c|c|}
\hline Keterangan & PSAK 28 & Hasil Penelitian & Kesimpulan \\
\hline Penerimaan premi & $\begin{array}{l}\text { pendapatan langsung: } \\
\text { Kas } \\
\text { Pendapatan Premi } \\
\end{array}$ & $\begin{array}{l}\text { Perusahaan mencatat: } \\
\text { Kas } \\
\quad \text { Pendapatan Premi } \\
\end{array}$ & $\begin{array}{l}\text { Diterapkan } \\
\text { (Sesuai) }\end{array}$ \\
\hline Pembayaran Klaim & $\begin{array}{l}\text { Diakui sebagai Beban Klaim: } \\
\text { Beban Klaim } \\
\quad \text { Kas }\end{array}$ & $\begin{array}{l}\text { Beban Kalim } \\
\text { Kas }\end{array}$ & $\begin{array}{l}\text { Diterapkan } \\
\text { (Sesuai) }\end{array}$ \\
\hline $\begin{array}{l}\text { Pendapatan } \\
\text { Underwriting }\end{array}$ & $\begin{array}{ll}\text { Premi Bruto }- \text { Premi Reasuransi } & \text { Premi Bru } \\
\pm \text { Kenaikan/Penurunan Premi } & \pm \text { Kenaik } \\
\text { yang belum merupakan penda- } & \text { yang belu } \\
\text { patan } & \\
\text { patan }\end{array}$ & $\begin{array}{l}\text { Premi Bruto - Premi Reasuransi } \\
\pm \text { Kenaikan/Penurunan Premi } \\
\text { yang belum merupakan penda- } \\
\text { patan }\end{array}$ & $\begin{array}{l}\text { Diterapkan } \\
\text { (Sesuai) }\end{array}$ \\
\hline $\begin{array}{l}\text { Investasi } \\
\text { (Hasil dari pendapat- } \\
\text { an underwriting di in- } \\
\text { vestasikan ke berba- } \\
\text { gai instrumen invest- } \\
\text { tasi) }\end{array}$ & $\begin{array}{lc}\text { Investasi merupakan salah satu } & \text { Cash on ba } \\
\text { kegiatan pengelolaan keuangan } & \text { Penda } \\
\text { yang utama diluar usaha asuransi. } & \text { Deposito } \\
\text { Guna memperoleh keuntungan, } & \text { Kas } \\
\text { menjamin solvabilitas perusaha- } & \text { Reksadana } \\
\text { an, menunjang operasional asu- } & \text { Kas } \\
\text { ransi (pembayaran klaim) } & \text { Efek sahar } \\
& \text { Kas }\end{array}$ & $\begin{array}{l}\text { Cash on bank } \\
\text { Pendapatan premi } \\
\text { Deposito } \\
\text { Kas } \\
\text { Reksadana } \\
\text { Kas } \\
\text { Efek saham } \\
\quad \text { Kas }\end{array}$ & $\begin{array}{l}\text { Diterapkan } \\
\text { (Sesuai) }\end{array}$ \\
\hline Hasil Investasi & $\begin{array}{l}\text { Hasil Investasi diakui sebagai } \\
\text { Pendapatan Perusahaan }\end{array}$ & $\begin{array}{l}\text { Kas } \\
\quad \text { Pendapatan Investasi }\end{array}$ & $\begin{array}{l}\text { Diterapkan } \\
\text { (Sesuai) }\end{array}$ \\
\hline \multicolumn{4}{|c|}{ b. Produk Asuransi Syariah } \\
\hline Keterangan & PSAK 108 & Hasil Penelitian & $\begin{array}{c}\text { Kesimpula } \\
\mathrm{n}\end{array}$ \\
\hline $\begin{array}{c}\text { Penerimaan } \\
\text { Premi/Kontribusi } \\
\text { (berdasarkan akad yang } \\
\text { digunakan) }\end{array}$ & $\begin{array}{l}\text { Kontribusi peserta diakui sebagai penda- } \\
\text { patan dana Tabarru'. } \\
\text { Bagian kontribusi untuk Ujrah diakui } \\
\text { sebagai pendapatan entitas pengelola dan } \\
\text { menjadi beban Dana Tabarru' }\end{array}$ & $\begin{array}{l}\text { Kas } \\
\quad \text { Pendapatan Tabarru' } \\
\text { Kas } \\
\quad \text { Pendapatan Ujrah }\end{array}$ & $\begin{array}{l}\text { Diterapkan } \\
\text { (Sesuai) }\end{array}$ \\
\hline Pembayaran Klaim & $\begin{array}{l}\text { Pembayaran manfaat atau Klaim } \\
\text { Asuransi berasal dari dana peserta secara } \\
\text { kolektif (Dana Tabarru') yang mana risiko } \\
\text { ditanggung secara bersama antar peserta }\end{array}$ & $\begin{array}{l}\text { Beban Klaim } \\
\text { Dana Tabarru, }\end{array}$ & $\begin{array}{l}\text { Diterapkan } \\
\text { (Sesuai) }\end{array}$ \\
\hline \begin{tabular}{l}
\multicolumn{2}{c}{ Investasi } \\
(Saldo Dana Tabarru' \\
dan Saldo Dana Waka- \\
lah diinvestasikan ke \\
instrumen investasi \\
syariah)
\end{tabular} & $\begin{array}{l}\text { Perlakuan akuntansi untuk investasi atas } \\
\text { dana Tabarru' dan dana wakalah mengacu } \\
\text { pada PSAK yang relevan. }\end{array}$ & $\begin{array}{l}\text { Depsito Syariah } \\
\text { Dana Tabarru' } \\
\text { Sukuk } \\
\text { Dana Tabarru' } \\
\text { Deposito/Sukuk } \\
\text { Dana Tabarru' } \\
\end{array}$ & $\begin{array}{l}\text { Diterapkan } \\
\text { (Sesuai) }\end{array}$ \\
\hline $\begin{array}{l}\text { Hasil Investasi } \\
\text { terdapat pembagian ha- } \\
\text { sil antara peserta asura- } \\
\text { nsi dengan perusahaan } \\
\text { asuransi sesuai akad } \\
\text { yang di sepakati }\end{array}$ & $\begin{array}{l}\text { Sebagian hasil investasi menjadi } \\
\text { Ujrah/fee di akui sebagai pendapatan } \\
\text { entitas pengelola (perusahaan) dan } \\
\text { sebagian sisanya di alokasikan ke saldo } \\
\text { dana Tabarru' }\end{array}$ & $\begin{array}{l}\text { Kas } \\
\text { Pendapatan investasi } \\
\text { Dana Tabarru' } \\
\text { Pendapatan Investasi }\end{array}$ & $\begin{array}{l}\text { Diterapkan } \\
\text { (Sesuai) }\end{array}$ \\
\hline
\end{tabular}

\section{2) Pengalokasian dana Investasi syariah dan Konvensional}

a. Investasi Produk Syariah

Kegiatan investasi yang dilakukan PT Asuransi Asei Indonesia atas dana dari produk asuransi syariah. Harus terdiri dari instrumen investasi syariah atau kekayaan yang telah ditentukan dalam PMK No. 11/PMK.010/2011 pasal 5. adalah sebagai berikut:

a) Deposito pada Bank Syariah,

b) Saham Syariah,

c) Sukuk atau Obligasi Syariah

d) Surat Berharga Syariah Negara 
e) Surat berharga yang diterbitkan oleh Bank Indonesia

f) Surat Berharga Syariah yang diterbitkan oleh selain Negara Republik Indonesia

g) Surat berharga syariah yang diterbitkan oleh lembaga multinasional yang Negara Republik Indonesia menjadi salah satu anggota atau pemegang sahamnya,

h) Reksadana syariah,

i) Efek beragam aset syariah yang diterbitkan berdasarkan kontrak investasi kolektif efek beragun aset syariah,

j) Pembiayaan melalui mekanisme kerjasama dengan pihak lain dalam bentuk pembelian pembiyaan (refinancing) syariah, dan/atau

k) Emas Murni.

Sedangkan instrumen investasi yang dipilih perusahaan sampai pada 31 Desember 2015 yang tercatat dalam laporan posisi keuangan PT Asuransi Asei Indonesia atas produk syariah adalah:

1) Deposito berjangka Syariah

Diinvestasikan ke berbagai Bank Umum Syariah, Bank yang memilki cabang syariah dan BPD Syariah. Dalam bentuk deposito jangka pendek sebgai pihak ketiga dan pihak berelasi.

2) Obligasi/Sukuk

a) Diinvestasikan ke Obligasi Syariah BUMN, Obligasi Syariah swasta, dan surat berharga syariah yang dijamin pemerintah (SBNN).

b) Obligasi dimiliki hingga jatuh tempo (HTM)

c) Obligasi tersedia untuk dijual

\section{b. Investasi Produk Konvensional}

Berbeda penerapannya, investasi yang dilakukan perusahaan atas produk asuransi konvensional. Jenis investasi yang di perkenankan diatur dalam PMK No.53/PMK.010/2012 yaitu:

a) Deposito berjangka dan sertifikat deposito pada bank termasuk deposit on call dan deposito yang berjangka waktu kurang dari atau sama dengan satu bulan.

b) Saham yang tercatat di bursa efek.

c) Surat berharga yang diterbitkan oleh Negara Republik Indonesia dan selain Negara Republik Indonesia

d) Surat berharga yang diterbitkan oleh Bank Indonesia.

e) Unit penyertaan reksadana.

f) Penyertaan langsung (saham yang tidak tercatat di bursa efek)

g) Bangunan dengan hak strata atau tanah dengan bangunan untuk investasi.

h) Emas murni dan/atau,

i) Pinjaman yang dijamin dengan hak tanggungan

Untuk itu dalam upaya memenuhi Peraturan Menteri Keuangan diatas perusahaan dalam hal ini telah memilih instrumen investasi yang sesuai dengan ketentuan-ketentuan yang telah ditetapkan dan wajib untuk dilakukan. jenis investasi yang telah dimiliki PT.Asuransi Asei Indonesia atas produk asuransi konvensional adalah:

1) Investasi dengan Pihak Ketiga:

a) Deposito berjangka

b) Reksadana

c) Obligasi

d) Saham

2) Investasi dengan Pihak Berelasi:
a) Deposito berjangka
b) Obligasi
c) Saham
d) Penyertaan langsung 


\section{3) Pembagian hasil Investasi}

Pada Produk asuransi syariah yang menggunakan akad Wakalah bil Ujrah, PT Asuransi Asei Indonesia melakukan penetapan bagi hasil atas hasil investasi antara perusahaan dan peserta yakni 50\% untuk Ujrah Perusahaan yang diakui sebagai pendapatan investasi dan 50\% sisanya untuk peserta yang langsung dialokasikan sebagai dana cadangan Tabarru' untuk peserta. Selain itu perusahaan juga akan mendapatkan wakalah fee sebesar $40 \%$ dari jumlah kontribusi. Penjelasan diatas dapat diilustrasikan sebagai berikut:
Kontribusi Peserta
Biaya materai \& administrasi
: Rp. 5,000,000,-
Ujrah/fee (40\% x 5.000.000)
: (Rp. 20,000)
Kontribusi (dana Tabarru') bersih
: (Rp. 2,000,000)
Invstasi dana Tabarru'
: Rp. 2,980,000,-
:Rp. 2,980,000,-
Return investasi (asumsikan 30\%)
$30 \%$ x Rp. 2,980,000
: Rp. 894,000,-
Ujrah (50\% x Rp. 894,000)
: (Rp. 447,000)
Cadangan dana Tabarru' 50\%
Pendapatan perusahaan $=$ Wakalahfee + Ujrah
$=$ Rp. $2,000,000+$ Rp. 447,000
$=$ Rp. 2,447,000,-

Sedangkan untuk produk asuransi konvensional yang dimiliki PT Asuransi Asei Indonesia mengakui hasil investasi sebagai pendapatan investasi. Hasil investasi tersebut merupakan hak perusahaan seutuhnya yang kelak dalam RUPS akhir tahun dibagikan kepada pemegang saham atau dikembalikan lagi sebagai penyertaan modal.

\section{KESIMPULAN DAN SARAN}

\section{Kesimpulan}

Dari hasil Penelitian yang dilakukan, beserta data yang didapat. Maka penulis dapat menarik kesimpulan dalam studi kasus yang dilakukan atas PT Asuransi Asei Indonesia. Yakni sebagai berikut:

1. Perusahaan telah menerapkan akuntansi dana investasi yang seusai dengan standar yang berlaku yakni PSAK 108 untuk produk asuransi umum syariah dan PSAK 28 untuk produk asuransi umum konvensional. Perbedaan pengelolaan dana investasi antara Produk Asuransi Syariah dengan Produk Asuransi Konvensional yang dimiliki PT Asuransi Asei Indonesia, terletak pada akad yang digunakan dalam memperlakukan premi/kontribusi, sumber dan penempatan alokasi dana investasi, serta mekanisme perlakuan terhadap bagi hasil investasi perusahaan.

2. PT Asuransi Asei Indonesia memisahkan aliran dana antara produk asuransi syariah dan konvesional untuk menempatkan dana investasi ke dalam instrumen investasi yang sesuai ketentuan masing-masing dengan mengikuti peraturan PMK No. 11/PMK.010/2011 pasal 5 untuk instrumen investasi syariah dan PMK No. 53/PMK.010/2012 pasal 4 untuk instrumen investasi konvensional. Dari hasil investasi yang diperoleh, produk asuransi syariah perusahaan telah melakukan bagi hasil antara perusahaan 50\% dan Peserta 50\% sesuai dengan akad wakalah bil ujrah yang disepakati. Hal ini juga telah sesuai dengan peraturan yang tercantum pada PSAK 108 tentang akuntansi transaksi asuransi syariah.

\section{Saran}

1) Perusahaan harus patuh tehadap batasan investasi yang dikeluarkan oleh regulator. Tujuan batasan investasi bagi perusahaan adalah untuk mengamankan dana yang dihimpun dari masyarakat yang telah diamanahkan kepada perusahaan untuk diinvestasikan ke instrumen yang aman, untuk meminimalkan risiko dalam berinvestasi dan memenuhi target return yang dianggarkan perusahaan. sehingga penting bagi perusahaan untuk dapat memenuhi 
batasan investasi yang dibuat oleh regulator.

2) Dalam produk asuransi syariah PT Asuransi Asei Indonesia perlu untuk melakukan investasi ke instrumen lain yang masih dalam batasan seperti, Saham Syariah, Surat Berharga Syariah Negara (SBSN), Obligasi Syariah, serta Reksadana Syariah. Dimana instrumen investasi tersebut dapat memberikan return untuk perusahaan yang cukup besar dibandingkan dengan hanya melakukan Deposito pada Bank Syariah.

3) Sebaiknya PT. Asuransi Asei Indonesia harus membuka Unit link Syariah untuk benarbenar memisahkan pencatatan dan pelaporan akuntansi antara produk asuransi konvensional dengan menggunakan PSAK 1,PSAK 28, dan PSAK yang relevan lainnya. dan produk syariah dengan menggunakan PSAK 101, PSAK 108 dan PSAK yang relevan lainnya. agar meminimalisir terjadinya salah saji dan tumpang tindih standar yang dipakai. Juga untuk memperjelas laporan keuangan dari produk syariah dan menambah kepercayaan peserta asuransi terhadap produk syariah yang ditawarkan perusahaan.

\section{DAFTAR PUSTAKA}

Ade N. Sawitri. 2012. Analisis Investasi dalam Asuransi Syariah Di Indonesia Terhadap Portofolio Optimal. Media Ekonomi Vol 19, No.2, Agustus 2012. Unversitas Trisakti. Surabaya. hal. 33

Ahmad Abrori, Catur Sasongko.2013. Analisis Pengelolaan Investasi Pada Asuransi Jiwa Syariah PT. ABC TAhun 2011 Berdasrakan PSAK 108 dan PMK. Jurnal FE UI. Diakses 12 Agustus 2016. Universitas Indonesia. Jakarta. hal. 5-6

Ahmad T Pasha \& Mher Mushtaq H. 2011. Conceptual and Operational Differences Between General Tafakul And Conventional Insurance. Australian Journal of Business and Managament Research Vol.1 No.8 Nop 2011. Bahauddin Zakariya university Multan. Pakistan. hal. 23

Djoko Muljono. 2015. Buku Pintar Akuntansi Perbankan dan Lembaga Keuangan Syariah. ANDI. Yogyakarta

Hafiza Tahira \& Zeeshan Arshad. 2014. Comparative Performance of Islamic and Conventional Insurance Companies in Pakistan. e-ISSN Vol. 16, Issue 6. Ver.II (jun. 2014) www.iosrjournal.org. University of Gujrat. Pakistan. hal 33.

Husin, Baharuddin. 2016. "Islam Dann Ekonomi" Dalam Fordeby, Adesy, Akuntansi Syariah : Seri Konsep Dan Aplikasi Ekonomi dan Bidnid. Cetakan Pertama. Rajawali Pers. Jakarta

Indrianto, Supomo. 2014. Metode Penelitian. Gramedia. Jakarta

Indry T. Horman, 2016. Analisis Penerapan Psak No.36 Tentang Akuntansi Kontrak Asuransi Jiwa Pada PT. Asuransi Jiwasraya (Persero) Cabang Manado. Jurnal Emba Vol4 No.1 Maret 2016, Hal. 924-933.Unsrat. Manado

Nurul Ichsan. 2016. Peluang dan Tantangan Inovasi Produk Asuransi Umum Syariah. Jurnal Ekonomi Islam Volume 7 Nomor 2 September 2016. UIN Syarif Hidayatullah. Jakarta. hal 133

Peraturan Menteri Keuangan RI No. 11/PMK.010/2011 tanggal 12 Januari 2011 tentang Kesehatan Keuangan Usaha Asuransi dan Usaha Reasuransi dengan Prinsip Syariah

PSAK No. 28 (revisi 2012) Akuntansi Asuransi Kerugian. Ikatan Akuntan Indonesia. Jakarta

PSAK No.108 (revisi 2015) Akuntansi Transaksi Asuransi Syariah. Ikata Akuntansi Indonesia. Jakarta

Republik Indonesia Undang-Undang No.40 tahun 2014 Tentang Perasuransian

Winata Suwarjeni. 2014. Metodologi Penelitian Lengkap. Praktis dan mudah dipahami. Pustaka Baru Press. Yogyakarta

Zybery, Hirjana, Lindita Rova. 2014. The Role Of The Accountants in the Frame Work Of Modern Technological Developments and Digital Accounting System.Europan Scientific Journal (24) 1857-7431). University Of Gijirokastra, Albania 